Töke, Lilla. "Portuges, Catherine and Peter Hames, eds. 2013. Cinemas in Transition in Central and Eastern Europe after 1989." Hungarian Cultural Studies. e-Journal of the American Hungarian Educators Association, Volume 7

\title{
Portuges, Catherine and Peter Hames, eds. 2013. Cinemas in Transition in Central and Eastern Europe after 1989. Philadelphia: Temple University Press. 279 pp.
}

\section{Reviewed by Lilla Tőke, Assistant Professor, CUNY, LaGuardia Community College}

The tumultuous post-1989 political, economic, and social changes in Central and Eastern Europe, no doubt, have substantially affected the region's cultural production. The film industry, which depends heavily on financial and technological investment, underwent perhaps the most dramatic transformation. As production, distribution, and viewing practices adjusted to the new economic reality, film's role as an art form and a venue of mass entertainment was also quickly redefined after 1989. Cinema in Transition in Central and Eastern Europe after 1989, edited by Catherine Portuges and Peter Hames, makes a brave attempt to account for the complex changes in the region's film industries and film aesthetics.

According to the editors, there is an intellectual need for such a collection because "the cultural realm, and cinema, which had played such a dramatic role in past decades, has found itself largely ignored in the world of international and comparative film studies" (1). This statement is somewhat surprising given the fact that most contributors to the volume have dedicated most of their scholarship in the last fifteen years to studying post-socialist Eastern European film. Besides numerous articles published in Eastern and Western journals, for instance, Peter Hames' earlier book, entitled The Czech and Slovak Cinema: Themes and Traditions (Edinburgh: Edinburgh University Press, 2009), attempts to tease out complex stylistic and thematic patterns in the two nations' cinemas from the 1930s to 2000. Dina Iordanova, another contributor to the volume, also wrote comprehensively on post-socialist Yugoslavian cinema in her monograph, Cinema in Flames: Balkan Film, Culture, and the Media (London: British Film Institute (BFI) Publishing, 2001). Catherine Portuges wrote a definitive guide to Hungarian filmmaker Márta Mészáros' oeuvre entitled Screen Memories: the Hungarian Cinema of Márta Mészáros (Bloomington: Indiana University Press, 1993). Finally, Ewa Mazierska's Polish Postcommunist Cinema (Oxford: Peter Lang International Academic Publishers, 2007) deals directly with the same questions as the collection at hand.

Although the claim about the lack of relevant cinema studies in the Introduction of the volume is an overstatement, nevertheless the collection is pioneering in its attempt to offer a comparative overview of the region's landscape of film production in the post1989 era. Moreover, the scope of the volume is as admirable as it is wide ranging. Each chapter focuses on one nation's cinema and examines its particular shifts in production, exhibition and reception practices as well as the aesthetic, thematic and infrastructural

(cc) BY

ULIS D-Serle 
Töke, Lilla. "Portuges, Catherine and Peter Hames, eds. 2013. Cinemas in Transition in Central and Eastern Europe after 1989." Hungarian Cultural Studies. e-Journal of the American Hungarian Educators Association, Volume 7 (2014): http://ahea.pitt.edu DOI: 10.5195/ahea.2014.162

changes it has undergone due to the impact of globalization and privatization in the postsocialist Eastern Europe. In Chapter One, Dina Iordanova offers a thematic categorization of the post-socialist Bulgarian cinema. Chapter Two is a comprehensive study by Peter Hames that tackles the complex political, technological and aesthetic changes in Czech and Slovak film production after 1989. In Chapter Three we find Barton Byg's particularly intriguing account of the dismantling of Former East Germany's film production after the unification and its transformation from an actual film-producing state to an imaginary space on the screen.

Ewa Mazierska's analysis of post-socialist Polish cinema (in Chapter Five) is probably the most comprehensive in the entire volume in terms of both industry and film typology. Mazierska first provides a highly nuanced description of the ongoing manifold transformations in national film legislation, production and exhibition practices. In the second part of her essay, she showcases her in-depth understanding of the dominant themes, genres, and aesthetic choices in contemporary Polish cinema. In particular, she discusses the economic and aesthetic struggles of a younger generation of filmmakers ("Young Wolves") and the rise of such genres as historical and fantasy film, in addition to the politically charged contemporary comedies and 'film offowy' ("independent/art cinema"). By contrast to Mazierska's thorough treatment of Polish cinema, there are also researchers -- in particular Bogdan Stefãnescu and Sanda Foamente writing about Romanian film -- who chose to limit their scope to the 1990s. This is a problematic choice, since the New Romanian Cinema, which has surfaced in the early 2000s, is probably the most definitive development in post-socialist Eastern European cinema. Thus, without scrutinizing an incredibly talented, new generation of Romanian filmmakers, Stefănescu and Foamente's analysis in Chapter Six cannot be considered complete. Chapter Seven, authored by Bohdan Y. Nebesio, on Ukrainian filmmaking also limits itself to a brief five-year period between 1992 and 1997 as it outlines, in rather gloomy terms, the institutional transformation of post-USSR national cinema lead by a generation of filmmakers who were mostly active in the 1960s and 1970s. Finally, Andrew Horton's account of post-Yugoslav cinema in Chapter Eight is somewhat eclectic as it skips from Tito's recurring image in post-socialist cinema to the most productive generation of filmmakers educated at FEMA (the Prague School of Film) and finally ends with national film production in the successor states of the FormerYugoslavia. Yet, Horton's account is also insightful in that it reveals the influence of the murky and complex events in Yugoslavia's history, politics, and ethnic relations on its successor states' film industry after 1989.

Of central interest to this review is Catherine Portuges' contribution to the volume. In Chapter Four, Portuges gives an overview of the post-1989 reinvention of Hungarian film. Her essay is symptomatic of the challenge that each author had to face in their essay, namely to comprehensively address highly complex transformations affecting post-socialist cinema in terms of theme, genre, aesthetics, funding, national politics, viewership, and more. Portuges starts by tracing the beginnings of the transitional period back to the 1980s and introduces the most influential filmmakers who continued to define 
Töke, Lilla. "Portuges, Catherine and Peter Hames, eds. 2013. Cinemas in Transition in Central and Eastern Europe after 1989." Hungarian Cultural Studies. e-Journal of the American Hungarian Educators Association, Volume 7 (2014): http://ahea.pitt.edu DOI: 10.5195/ahea.2014.162

the landscape of Hungarian cinema after 1989. She then dedicates three sections to the works of Béla Tarr, Péter Forgács and to a few women filmmakers such as Márta Mészaros and Ibolya Fekete. She also outlines the multifaceted institutional changes in Hungarian post-socialist filmmaking, stating that despite their shortcomings, these new structures were better and more effective than the one they had replaced. Portuges ends her overview on a positive note, claiming that "national cinemas [are presently] gaining strength and focus in Eastern and Central Europe" (131). Her account about the state of post-socialist Hungarian national cinema, unfortunately, presently seems overly optimistic, since the current government has virtually destroyed national film production through its cultural politics. Portuges's article also touches briefly on issues of documentary filmmaking, the global circulation of Hungarian films, film festivals and post-socialist co-productions. Finally, we get a glance at the new generation of Hungarian filmmakers such as György Pálfi, Szabolcs Hajdu and Ágnes Kocsis, who grew up in the post-1989 period and whose work probably best reflects contemporary Hungarian society in its deep structural transformations.

For a film study volume, one shortcoming that needs mentioning is its lack of illustrations. It is briefly indicated in the Introduction that the images accompanying each chapter are available for online viewing, through a provided link. The publisher fell short of treating this volume with the respect that it deserves given its highly visual topic, as it is very unlikely that readers (like this reviewer) will interrupt their reading and take the time to look up the online material. To conclude, this new collection about post-socialist Eastern European national cinemas is necessarily eclectic and fragmentary. But so is the nature of the economic, cultural and political transitions it addresses, as well as the visual culture of post-socialist Eastern Europe that to this day still continues to transform. Therefore, Cinemas in Transition definitely makes a valuable read for those who seek to learn more about Central Europe and its more recent film production and film history. 